\title{
Progressive Collapse of Steel Frames
}

\author{
Kamel Sayed Kandil ${ }^{1}$, Ehab Abd El Fattah Ellobody ${ }^{2}$, Hanady Eldehemy ${ }^{{ }^{*}}$ \\ ${ }^{1}$ Department of Civil Engineering, Faculty of Engineering, Menoufiya University, Shibin El Kom, Egypt; ${ }^{2}$ Department of Structural \\ Engineering, Faculty of Engineering, Tanta University, Tanta, Egypt. \\ Email: "hanadyeldehemy@yahoo.com
}

Received August $19^{\text {th }}, 2013$; revised September $22^{\text {nd }}, 2013$; accepted September $27^{\text {th }}, 2013$

Copyright (C) 2013 Kamel Sayed Kandil et al. This is an open access article distributed under the Creative Commons Attribution License, which permits unrestricted use, distribution, and reproduction in any medium, provided the original work is properly cited.

\begin{abstract}
This paper investigates the behavior of steel frames under progressive collapse using the finite element method. Nonlinear finite element models have been developed and verified against existing data reported in the literature as well as against tests conducted by the authors. The nonlinear material properties of steel and nonlinear geometry were considered in the finite element models. The validated models were used to perform extensive parametric studies investigating different parameters affecting the behavior of steel frames under progressive collapse. The investigated parameters are comprised of different geometries, different number of stories and different dynamic conditions. The force redistribution and failure modes were evaluated from the finite element analyses, with detailed discussions presented.
\end{abstract}

Keywords: Finite Element Model; Multistory Buildings; Nonlinear Analysis; Progressive Collapse; Steel Frames

\section{Introduction}

Numerous studies were found in the literature highlighting the response of steel frames under progressive collapse. Earlier studies accounting for dynamic redistribution of forces in a progressive collapse scenario were carried out by Mc Connel (1983) [1], Casciati (1984) [2], and Pretlove (1986) [3]. Mc Connel (1983) [1] investigated the progressive collapse failure of warehouse racking, where local failure was initiated by truck collision or static overload. Several analytical studies of progressive collapse were conducted for simple buildings $[4,5]$ to validate analytical procedures and focus on obtaining fundamental aspects of the progressive collapse behavior. Progressive collapse resistant-design in steel frame buildings was studied by Gross and McGuire (1983) [4]. In his study, the behavior of 2-D moment resisting steel frames with the loss of one of the columns or increased load on the beams representing fallen debris was examined numerically. Pretlove (1986) [3] studied the dynamic effects that occur in the progressive failure of a simple uniaxial tension building and concluded that a building that appears to be safe under static load redistribution may actually be unsafe if the transient dynamic effects were taken into account. In another study, Pretlove (1991) [6] carried out experimental and numerical

${ }^{*}$ Corresponding author. investigations with a tension spoke building to examine the nature of progressive failure and dynamic effects associated with the loss of one or more spokes. Smith (1988) [7] evaluated the progressive collapse potential for space trusses using the alternate path method. The effect of member loss in a truss-type space building was examined by Malla (1995) [8] to evaluate the potential for progressive collapse. The dynamic effects associated with the sudden failure of a member due to brittle failure in the elastic region or due to buckling under compressive forces where the member snaps after reaching a critical load were included. Abedi (1996) [9] examined the behavior of single layer braced domes which was prone to progressive collapse due to propagation of local instability initiated by member or node instability. Also, Gilmour and Virdi (1998) [10] developed a computer program for planar steel and concrete frames, including effects of local damage, alternative load path and debris loads.

Kaewkulchai and Williamson (2003, 2004) [11,12] emphasized the importance of dynamic effects in a building experiencing progressive collapse. The study concluded that dynamically spreading effects of the response should be taken into account in analyzing a building under abnormal loading resulting in partial or global collapse.

Khandelwal (2007) [13] investigated the ductility be- 
havior and the ability of developing catenary action in a progressive collapse response of a seismically designed moment resistance frame. A seismically designed 8-story special moment resistance frame with reduced beam sections was considered in the investigation.

Kim and Park (2008) [14] investigated the progressive collapse vulnerability of steel moment frame buildings following the failure of a ground floor column. A 2-D finite element modeling and both nonlinear static and dynamic analyses following the alternate path method recommended by GSA guidelines (2003) [15] were utilized in the investigation. A 3- and 9-story steel building models conventionally designed to carry only gravity loads were considered in the investigations.

The above survey has shown that owing to the lack in full-scale tests on steel frames under progressive collapse, nonlinear 3-D finite element modeling can provide a better understanding of the behaviour of steel frames under progressive collapse. The main objective of this study is to model the progressive collapse behaviour. Nonlinear 2-D and 3-D finite element models were developed and verified against tests conducted by the authors as well as against results reported in the literature by other researchers. The verified finite element models developed in this study are used to perform parametric studies investigating different parameters affecting the performance of steel frames under progressive collapse. Numerous multi-story buildings, subject to uniform dead and live loads undergoing large deflections are analyzed. Four types of multi-story buildings with internal column removed with 2-D and 3-D frame model are investigated. These types are 3-, 6-, 9- and 12-story. Three aspect ratios are employed for each type: 1, 1:0.6 and 1:0.3 spans ratios. The analysis would be carried out by nonlinear dynamic analysis.

\section{Model Description}

Full-scale for buildings and analysis methods for progressive collapse were provided. In this paper, buildings were 3-bay 3- and 9-story buildings with square plan, and the span length was $6 \mathrm{~m}$. The building was studied by Jinkoo (2008) [16]. Figure 1 showed the structural plan and elevation of the 3-story building with $6 \mathrm{~m}$ span length. The exterior frame enclosed in the dotted rectangle was separated and analyzed for progressive collapse. The design dead and live loads are $5.0 \mathrm{kN} / \mathrm{m}^{2}$ and 3.0 $\mathrm{kN} / \mathrm{m}^{2}$ respectively.

The columns and beams were made of SM490 steel having a yield stress of $\mathrm{Fy}=32.4 \mathrm{kN} / \mathrm{cm}^{2}$ and SS400 steel having a yield stress of Fy $=23.5 \mathrm{kN} / \mathrm{cm}^{2}$, respectively. All columns are fixed end supports. The gravity load (dead load $+0.25 \times$ live load) applied on the model building with a first story column removed as indicated in the GSA guideline (2003) [15] for simulation of pro- gressive collapse. The load was suddenly applied for seven seconds on the model buildings with a first story column removed to activate vertical vibration. For other aspect ratios, see Figures 2 and 3.

Table 1 presents the ductility ratios in model structures with different number of story when the external and internal column was removed. The yield displacements were obtained by nonlinear static push-down analyses and the maximum displacements were computed from nonlinear dynamic analyses. The ductility

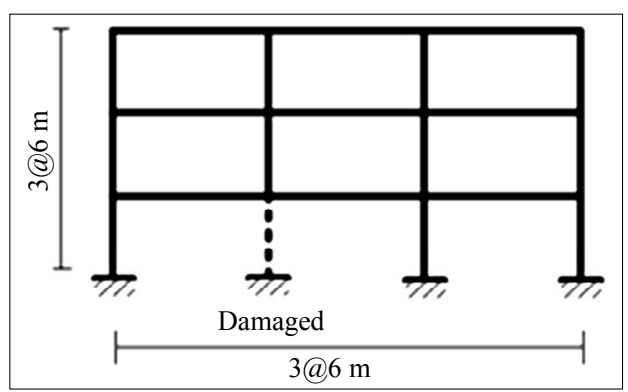

Figure 1. Analysis model building for aspect ratio 1.

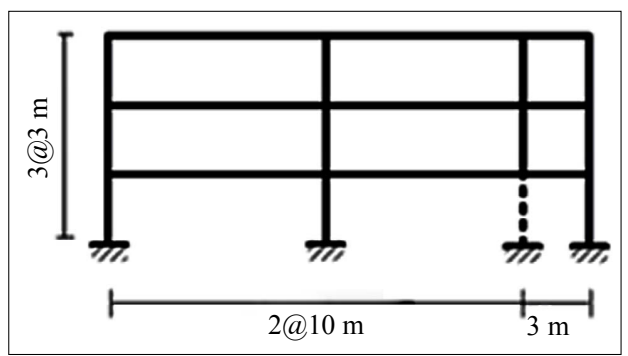

Figure 2. Analysis model building for aspect ratio 1:0.3.

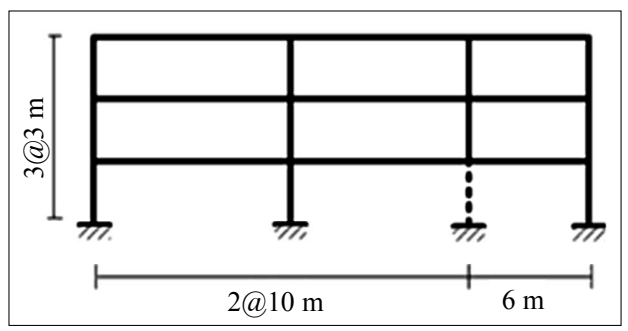

Figure 3. Analysis model building for aspect ratio 1:0.6.

Table 1. Ductility of model structures when the external and internal column was removed.

\begin{tabular}{ccc}
\hline $\begin{array}{c}\text { No. of } \\
\text { stories }\end{array}$ & $\begin{array}{c}\text { The DoD and GSA ductility for } \\
\text { external column was removed }\end{array}$ & $\begin{array}{c}\text { The DoD and GSA } \\
\text { ductility for internal } \\
\text { column was removed }\end{array}$ \\
\hline 3 & 90 & 60 \\
6 & 90 & 60 \\
9 & 90 & 60 \\
12 & 90 & 60 \\
\hline
\end{tabular}


ratio is the ratio of the maximum displacement and the yield displacement. The ductility ratio turned out to be large when the external column was removed and when the load specified in the DoD guideline [17] and GSA (2003) [15], was imposed on the structures.

\section{2-D Model Frame for Internal Column Removed with Equal Span}

Figure 4 showed the maximum lateral deflections of 2-D steel frame for 3-, 6-, 9- and 12-story buildings with equal span for internal column removed at damping ratio $2 \%$. The maximum lateral deflection for 3-story was higher than 6 and 9 story building, while the lateral deflection for 12-story having lower value than the other story by $25 \%$ and for the ductility ratio would be $3.73 \%$ for 3 -story, $3.51 \%$ for 6 -story, $3.32 \%$ for 9 -story and $2.98 \%$ for 12-story. The ductility ratio decreased as the number of story increased. Figure 5 showed the maximum lateral deflections of 2-D steel frame for 3-, 6-, 9- and 12-story buildings with equal span for internal column removed at damping ratio $5 \%$ and for the ductility ratio would be

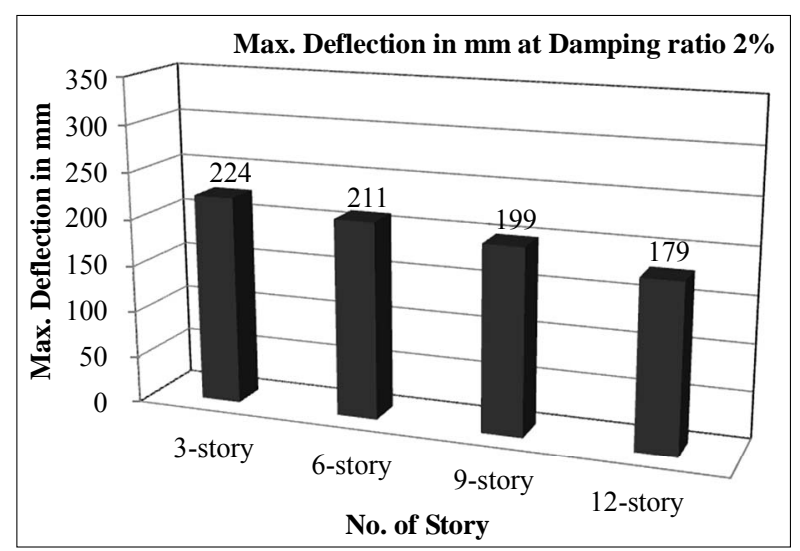

Figure 4. The maximum lateral deflections for 2-D steelframe for internal column removed at damping ratio $2 \%$.

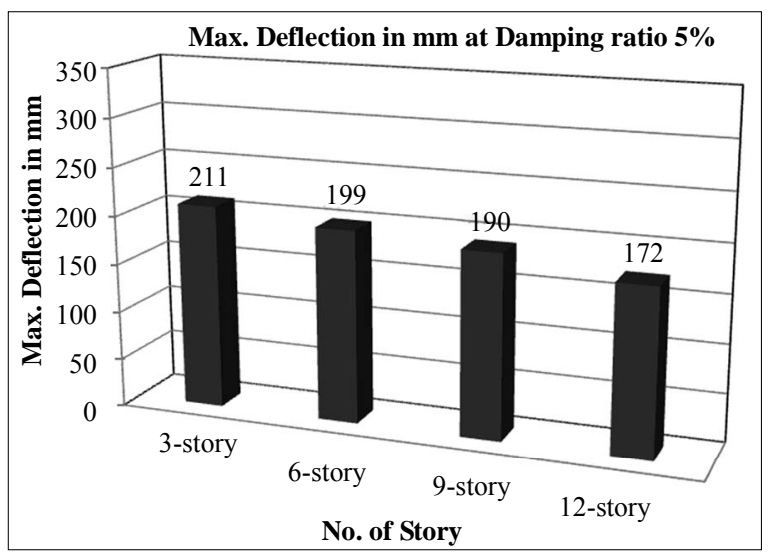

Figure 5. The maximum lateral deflections for 2-D steel frame for internal column removed at damping ratio $5 \%$.
$3.51 \%$ for 3 -story, $3.31 \%$ for 6 -story, $3.17 \%$ for 9 -story and $2.87 \%$ for 12 -story. The maximum lateral deflection for 3-story was higher than 6 and 9 story building, while the lateral deflection with 12-story having lower value than the other story by $22 \%$. Figure 6 showed the maximum lateral deflections of 2-D steel frame for 3, 6, 9 and 12 -story buildings with equal span for internal column removed at damping ratio $6 \%$ and for the ductility ratio would be $3.45 \%$ for 3 -story, $3.27 \%$ for 6 -story, $3.12 \%$ for 9 -story and $2.81 \%$ for 12 -story. The 3-story was higher than 6 and 9 story building, while the lateral deflection with 12-story having lower value than the other story by $22 \%$. Figure 7 showed the maximum lateral deflections of 2-D steel frame for 3-, 6-, 9- and 12-story buildings with equal span for internal column removed at damping ratio $8 \%$ and for the ductility ratio would be $3.33 \%$ for 3 -story, $3.16 \%$ for 6 -story, $3.04 \%$ for 9 -story and $2.75 \%$ for 12 -story. The maximum lateral deflection for 3-story was higher than 6 and 9 story building, while the lateral deflection for 12-story having lower value than the other story by $21 \%$. Figure 8 showed the maximum lateral deflections of 2-D steel frame for 3-, 6-, 9-

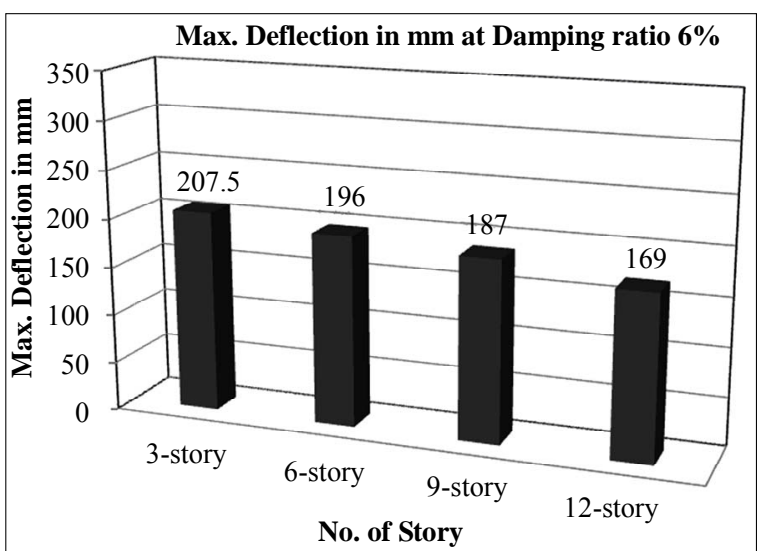

Figure 6. The maximum lateral deflections for 2-D steel frame for internal column removed at damping ratio $6 \%$.

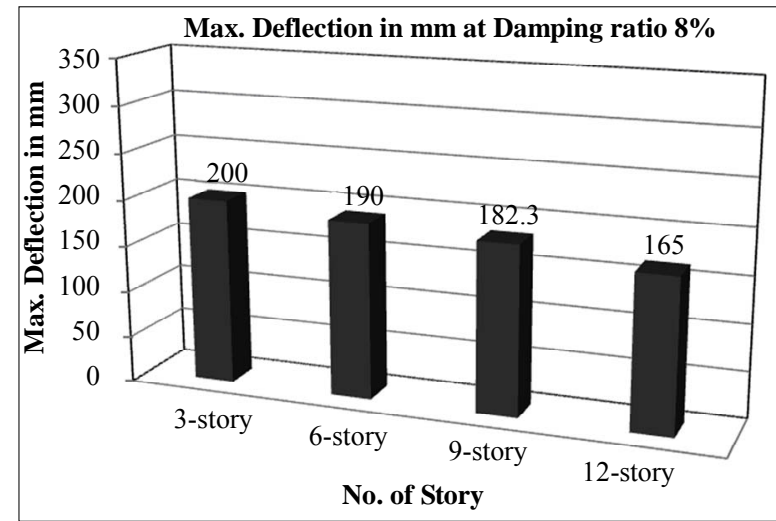

Figure 7. The maximum lateral deflections for 2-D steel frame for internal column removed at damping ratio $8 \%$. 
And 12-story buildings with equal span for internal column removed at damping ratio $10 \%$ and for the ductility ratio would be $3.25 \%$ for 3 -story, $3.08 \%$ for 6 -story, $2.97 \%$ for 9 -story and $2.7 \%$ for 12 -story. The maximum lateral deflection of 3-story was higher than 6- and 9story building, while the lateral deflection for 12-story having lower value than the other story by $20 \%$ and, for building and with increasing damping ratios the ductility ratios decreases.

\section{2-D Model Frame for Internal Column Removed with Span Ratio 1:0.6}

Figure 9 showed the maximum lateral deflections of 2-D steel frame for 3-, 6-, 9- and 12-story buildings with span ratio 1:0.6 for internal column removed at damping ratio $2 \%$. For 3-story the maximum lateral deflections was higher than 6 - and 9-story building by $12 \%$ which having slightly effects in the lateral deflection not more than $1 \%$. While the lateral deflection with 12-story having lower value than the other story by $26 \%$. Figure 10 showed the

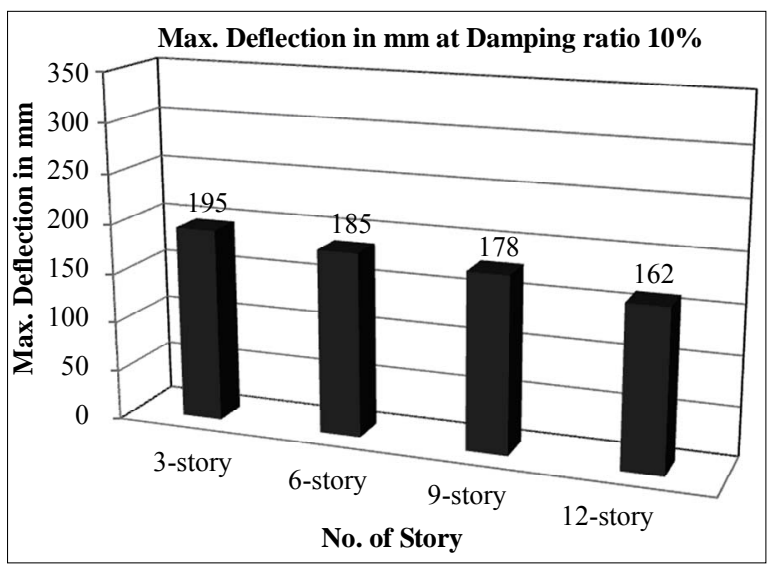

Figure 8. The maximum lateral deflections for 2-D steel frame for internal column removed at damping ratio $10 \%$.

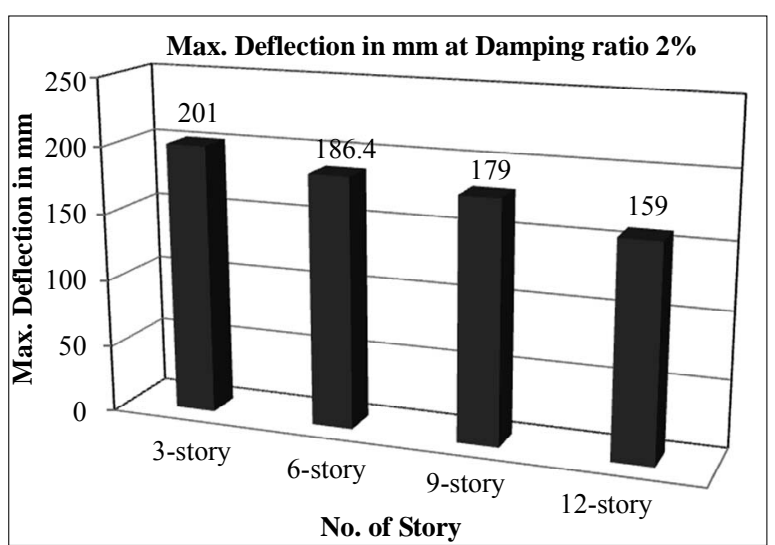

Figure 9. The maximum lateral deflections for 2-D steel frame for internal column removed and span ratio 1:0.6 at damping ratio $2 \%$. maximum lateral deflections of 2-D steel frame for 3-, 6-, 9- and 12-story buildings with span ratio 1:0.6 for internal column removed at damping ratio $5 \%$. The maximum lateral deflections of 3-story was higher than 6- and 9story building by $6.6 \%$ which having slightly effects in the lateral deflection not more than $1 \%$. While the lateral deflection for 12-story having lower value than the other story by $24.5 \%$.

Figure 11 showed the maximum lateral deflections of 2-D steel frame for 3-, 6-, 9- and 12-story buildings with span ratio 1:0.6 for internal column removed at damping ratio $6 \%$. The maximum lateral deflections of 3-story was higher than 6 - and 9 -story building by $10 \%$ which having slightly effects in the lateral deflection not more than $1 \%$. While the lateral deflection with 12 -story having lower value than the other story by $24 \%$. Figure 12 showed the maximum lateral deflections of 2-D steel frame for 3-, 6-, 9- and 12-story buildings with span ratio 1:0.6 for internal column removed at damping ratio $8 \%$. The maximum lateral deflections of 3-story was higher

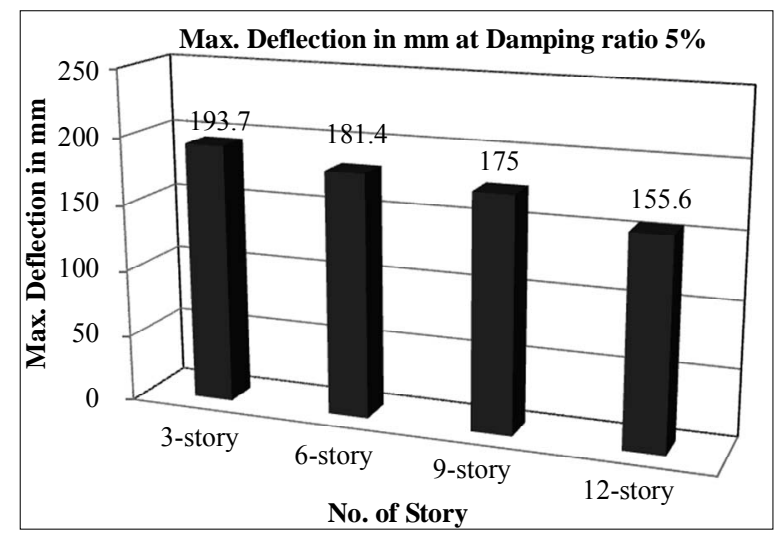

Figure 10. The maximum lateral deflections for 2-D steel frame for internal column removed with span ratio 1:0.6 at damping ratio $5 \%$.

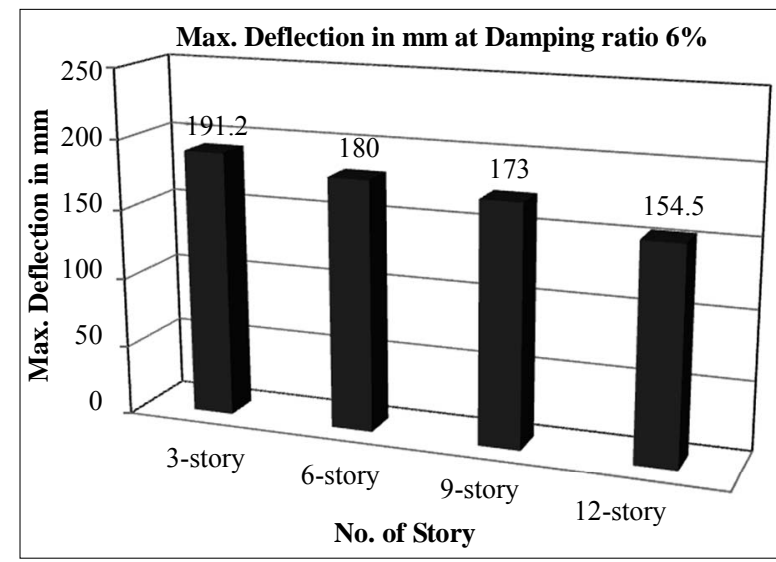

Figure 11. The maximum lateral deflections for 2-D steel frame for internal column removed with span ratio 1:0.6 at damping ratio $6 \%$. 
than 6 - and 9 -story building by $9 \%$ which having slightly effects in the lateral deflection not more than $1 \%$. While the lateral deflection with 12-story having lower value than the other story by $24 \%$. Figure 13 showed the maximum lateral deflections of 2-D steel frame for 3-, 6-, 9and 12-story buildings with span ratio 1:0.6 for internal column removed at damping ratio $10 \%$. The maximum lateral deflections for 3-story was higher than 6 and 9story building by $8.8 \%$ which having slightly effects in the lateral deflection not more than $1 \%$. While the lateral deflection for 12 -story having lower value than the other story by $22.5 \%$.

The progressive collapse potential decreased as the number of story increased since more structural members participate in resisting progressive collapse and increasing the damping ratios.

\section{2-D Model Frame for Internal Column Removed with Span Ratio 1:0.3}

Figure 14 showed the maximum lateral deflections of

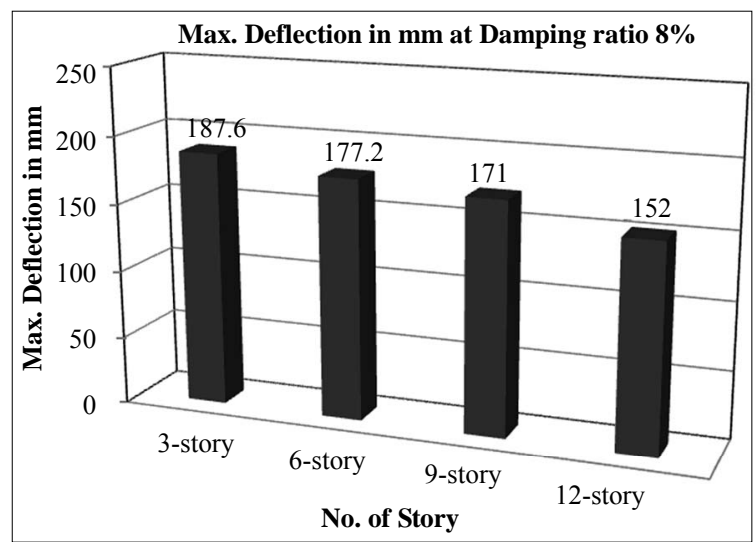

Figure 12. The maximum lateral deflections for 2-D steel frame for internal column removed with span ratio 1:0.6 at damping ratio $8 \%$.

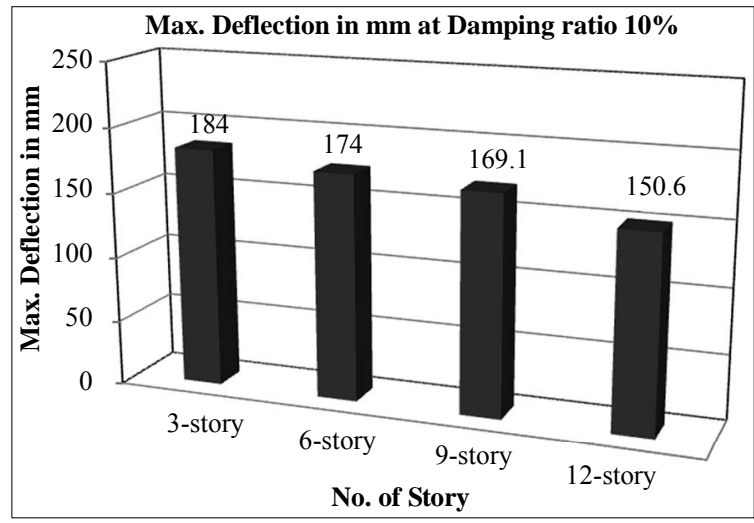

Figure 13. The maximum lateral deflections for 2-D steel frame for internal column removed with span ratio 1:0.6 at damping ratio $10 \%$.
2-D steel frame for 3-, 6-, 9- and 12-story buildings with span ratio 1:0.3 for internal column removed at damping ratio $2 \%$. The maximum lateral deflections for 3-story were higher than 6 - and 9-story building by $9 \%$ which have slightly effects in the lateral deflection not more than $1 \%$. While the lateral deflection with 12 -story have value higher than the other story by $60 \%$. Figure 15 showed the maximum lateral deflections of 2-D steel frame for 3-, 6-, 9- and 12-story buildings with span ratio 1:0.3 for internal column removed at damping ratio $5 \%$. The maximum lateral deflections for 3-story were higher than 6 - and 9 -story building by $9 \%$, which have slightly effects in the lateral deflection not more than $1 \%$. While the lateral deflection for 12-story having higher value than the other story by $60 \%$. Figure 16 showed the maximum lateral deflections of 2-D steel frame for 3-, 6-, 9and 12-story buildings with span ratio 1:0.3 for internal column removed at damping ratio $6 \%$. The maximum lateral deflections for 3-story was higher than 6- and 9 -story building by $9 \%$ which having slightly effects in

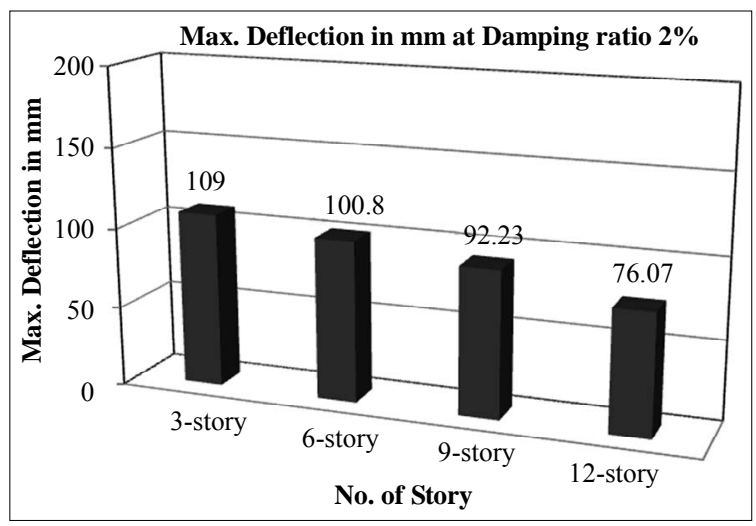

Figure 14. The maximum lateral deflections for 2-D steel frame for internal column removed with span ratio 1:0.3 at damping ratio $2 \%$.

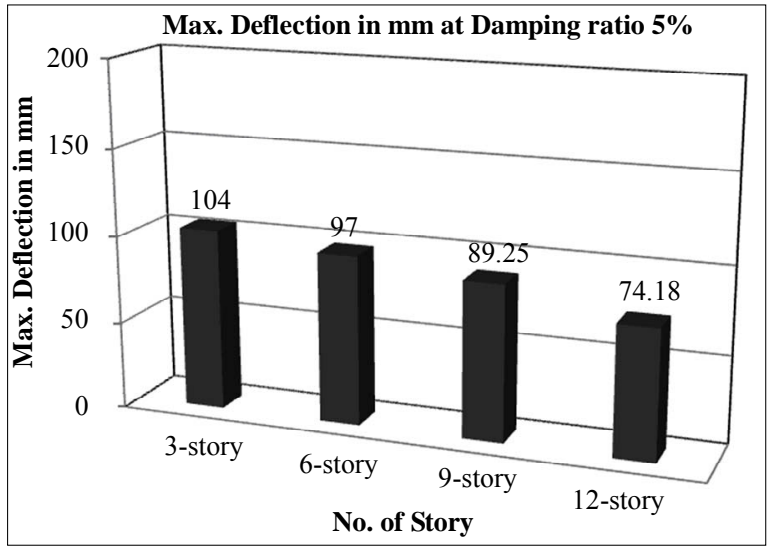

Figure 15. The maximum lateral deflections for 2-D steel frame for internal column removed with span ratio 1:0.3 at damping ratio $5 \%$. 
the lateral deflection not more than $1 \%$. While the lateral deflection for 12-story having higher value than the other story by $60 \%$. Figure 17 showed the maximum lateral deflections of 2-D steel frame for 3-, 6-, 9- and 12-story buildings with span ratio 1:0.3 for internal column removed at damping ratio $8 \%$. The maximum lateral deflections for 3-story was higher than 6- and 9-story building by $9 \%$ which have slightly effects in the lateral deflection not more than $1 \%$. While the lateral deflection for 12 -story has value higher than the other story by $60 \%$. Figure 18 showed the maximum lateral deflections of 2-D steel frame for 3-, 6-, 9- and 12-story buildings with span ratio 1:0.3 for internal column removed at damping ratio $10 \%$. The maximum lateral deflections for 3 -story were higher than 6- and 9-story building by $9 \%$, which have slightly effects in the lateral deflection not more than $1 \%$. While the lateral deflection for 12 -story having value higher than the other story by $60 \%$. It observed from the above figures that the progressive collapse potential decreased as the number of story increased since

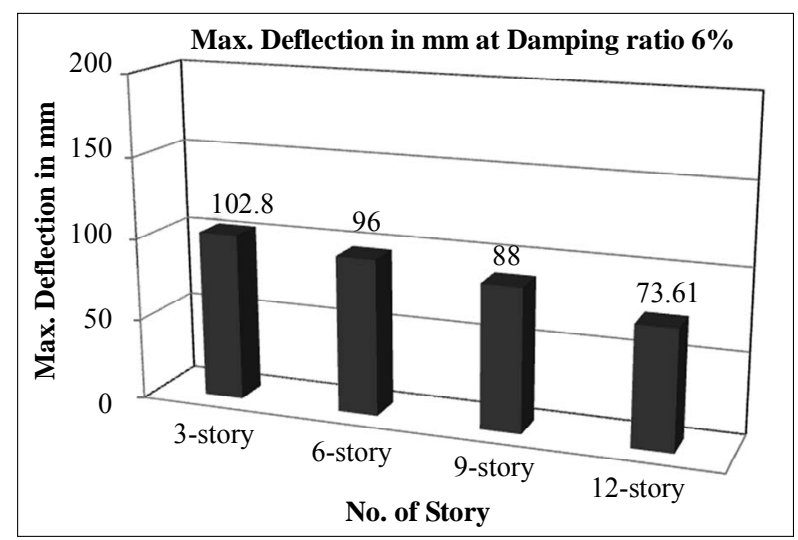

Figure 16. The maximum lateral deflections for 2-D steel frame for internal column removed with span ratio $1: 0.3$ at damping ratio $6 \%$.

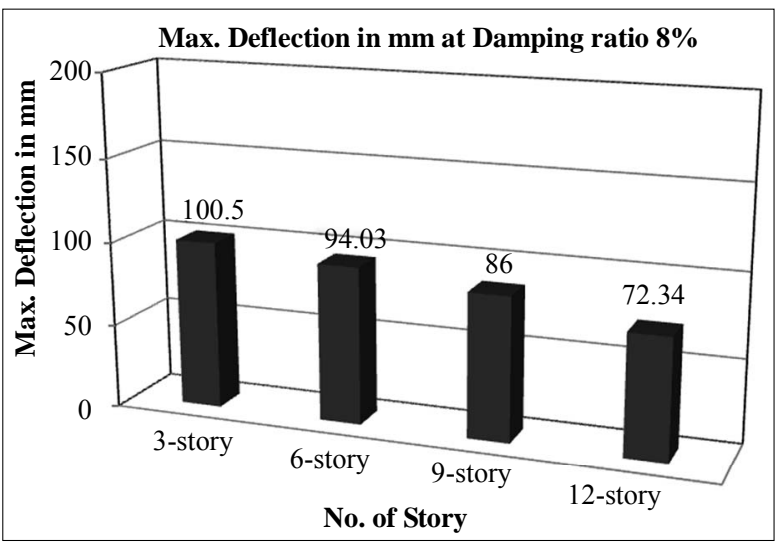

Figure 17. The maximum lateral deflections for 2-D steel frame for internal column removed with span ratio 1:0.3 at damping ratio $8 \%$. more structural members participate in resisting progressive collapse and increasing the damping ratios.

\section{The Maximum Deformation for 2-D Frame for Internal Column Removed}

\subsection{Equal Span}

Figure 19 showed the maximum deformation for 2-D steel frame for 3-story buildings with equal span and damping ratio $5 \%$ for interior column removed. Figure 20 showed the maximum lateral deflections from Jinkoo (2008) [16], 2-D and 3-D steel frame with 3-story buildings with equal span and different damping ratios when the interior column was removed for nonlinear dynamic analysis. At damping ratio $2 \%$, the maximum lateral deflection for 3-D steel frame was higher than the maximum lateral deflection for 2-D steel frame building by $1.8 \%$. The maximum lateral deflection for 2-D steel frame was higher than the maximum lateral deflection for Jinkoo (2008) [16], by $1.8 \%$. In damping ratio $5 \%$, the maximum lateral deflection for 3-D steel frame was higher than the maximum lateral deflection for 2-D steel frame building by $0.9 \%$. For $2-\mathrm{D}$ steel frame the maxi-

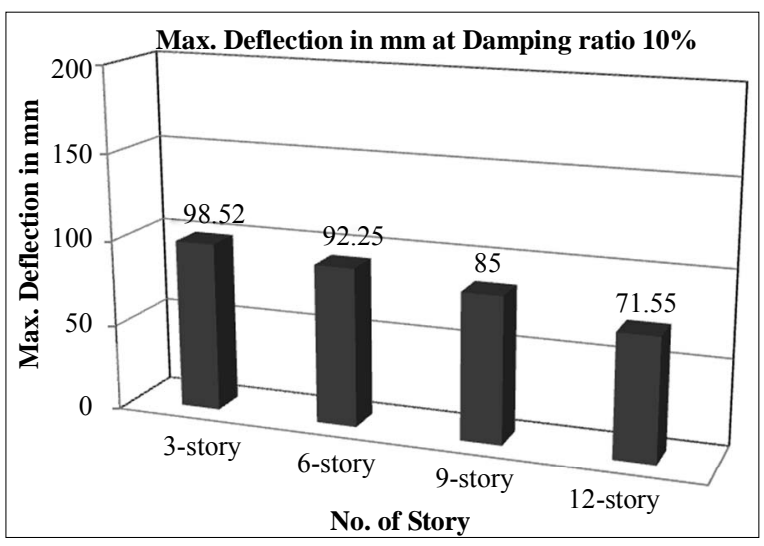

Figure 18. The maximum lateral deflections for 2-D steel frame for internal column removed with span ratio 1:0.3 at damping ratio $10 \%$.

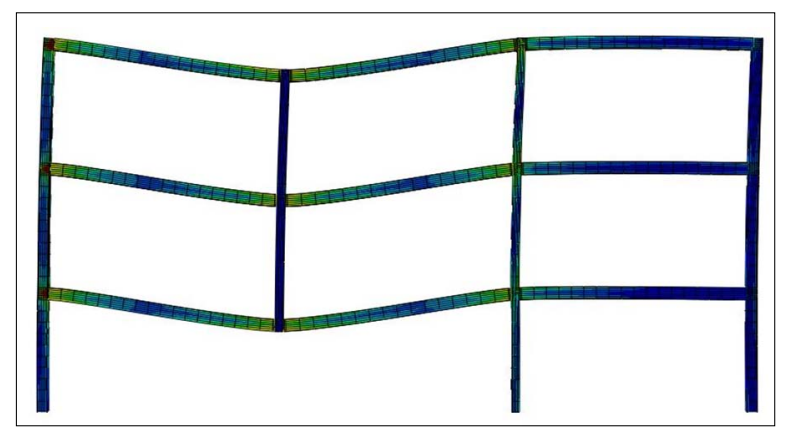

Figure 19. The maximum deformation for 2-D steel frame for 3-story building for interior column removed with equal span. 
mum lateral deflection was higher than the maximum lateral deflection for Jinkoo (2008) [16], by 5.5\%. At damping ratio $10 \%$, the maximum lateral deflection for 3-D steel frame was higher than the maximum lateral deflection for $2-\mathrm{D}$ steel frame building by $3 \%$. The maximum lateral deflection for 2-D steel frame was higher than the maximum lateral deflection for Jinkoo (2008) [16], by $25.8 \%$. The vertical deflection of the building decreased as the damping ratio increased. The maximum deflection of the building with $2 \%$ and $5 \%$ damping ratio slightly exceeded the allowable value of limit state specified in the GSA guidelines (2003) [15], while in $10 \%$ damping ratio, the maximum deflection of the building was less the allowable value of limit state specified in the GSA guidelines (2003) [15]. Figure 21 showed the maximum deformation for 2-D steel frame for 9-story buildings with equal span and damping ratio $5 \%$ for interior column removed. Figure 22 showed the maximum lateral deflections of Jinkoo (2008) [16] and 2-D steel frame for 9-story buildings with equal span and damping

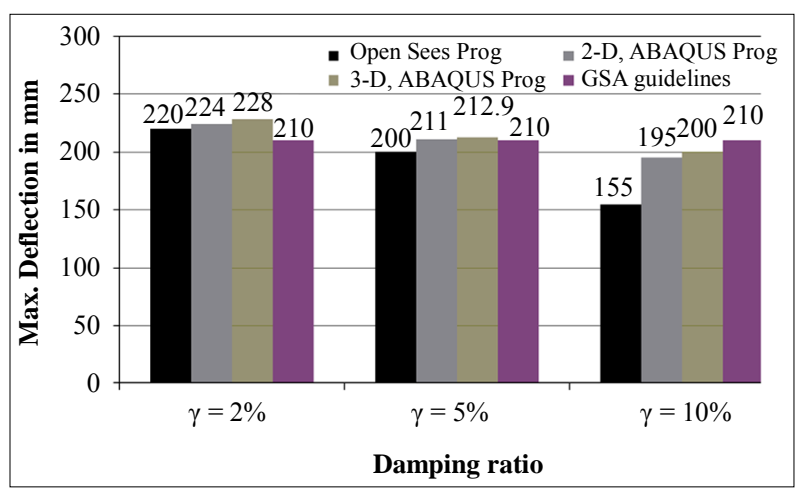

Figure 20. The maximum lateral deflections of Jinkoo (2008) [16], 2-D and 3-D steel frame with equal span for interior column removed.

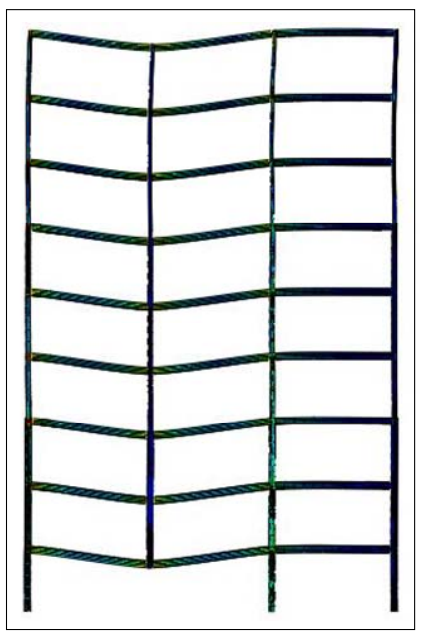

Figure 21. The maximum deformation for 2-D steel frame for 9-Story building with equal span. ratio $5 \%$ for interior column removed, the maximum lateral deflection for 2-D steel frame was less than the maximum lateral deflection for Jinkoo (2008) [16] by $4.7 \%$, and less than the allowable value of limit state specified in the GSA guidelines (2003) [15]. Figure 23 showed the maximum deformation for 3-D steel frame with 3-story buildings with equal span and damping ratio $5 \%$ for interior column removed.

\subsection{Span Ratio 1:0.6}

Figure 24 showed the maximum deformation for 2-D steel frame for 3-story buildings with span ratio 1:0.6 for long span $10 \mathrm{~m}$, short span $6 \mathrm{~m}$ and damping ratio $5 \%$ for interior column removed. Figure 25 showed the maximum lateral deflections of Jinkoo (2008) [16], 2-D steel frame for 3-story buildings with span ratio 1:0.6 at damping ratio $5 \%$ for interior column removed, the maximum lateral deflection for 2-D steel frame was higher than the maximum lateral deflection for from Jinkoo (2008) [16], by $7.6 \%$ but less than the allowable value of limit state specified in the GSA guidelines (2003) [15].

\subsection{Span Ratio 1:0.3}

Figure 26 showed the maximum deformation for 2-D

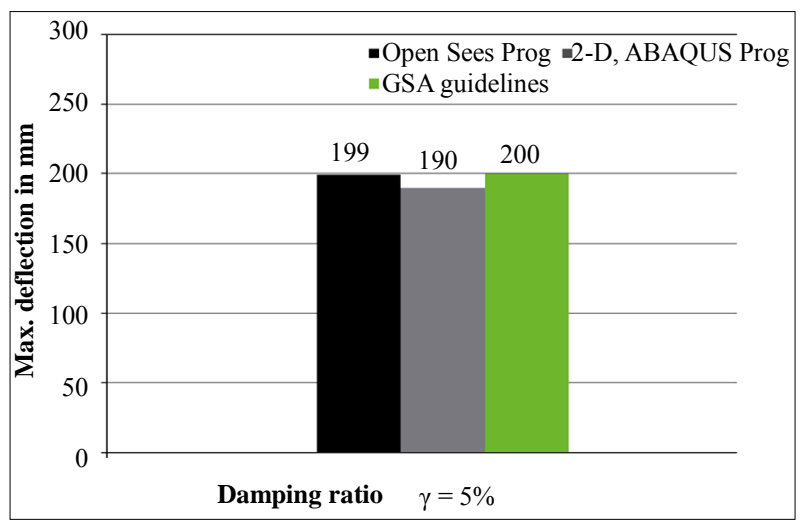

Figure 22. The maximum lateral deflections of Jinkoo (2008) [16], and 2-D steel frame for 3-story building for interior column removed.

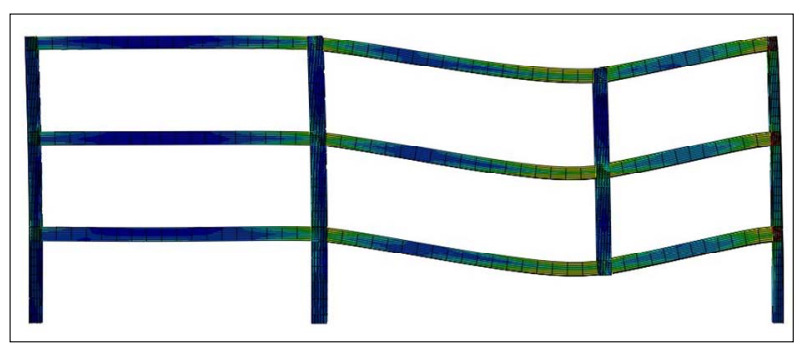

Figure 23. The maximum deformation for 2-D steel frame for 3-story building for interior column removed and span ratio 1:0.6. 
steel frame for 3-story buildings with span ratio 1:0.3 for long span $10 \mathrm{~m}$, short span $3 \mathrm{~m}$ and damping ratio $5 \%$ for interior column removed. Figure 27 showed the maximum lateral deflections of Jinkoo (2008) [16], 2-D steel frame for 3-story buildings with span ratio 1:0.3 and damping ratio $5 \%$ for interior column removed. The maximum lateral deflection for 2-D steel frame was higher than the maximum lateral deflection for Jinkoo (2008) [16] by $5 \%$ and less than the allowable value of limit state specified in the GSA guidelines (2003) [15].

Figure 28 presented the time history of the vertical displacement for the internal column removed at different values of damping ratio for 3-story building with equal span. The progressive collapse potential decreased as the number of story increased since more structural members participate in resisting progressive collapse and increasing the damping ratios. It observed also the damping ratio $2 \%$ having the maximum value that was due the energy was dissipated from the building was small value, the system contained small losses the mass could

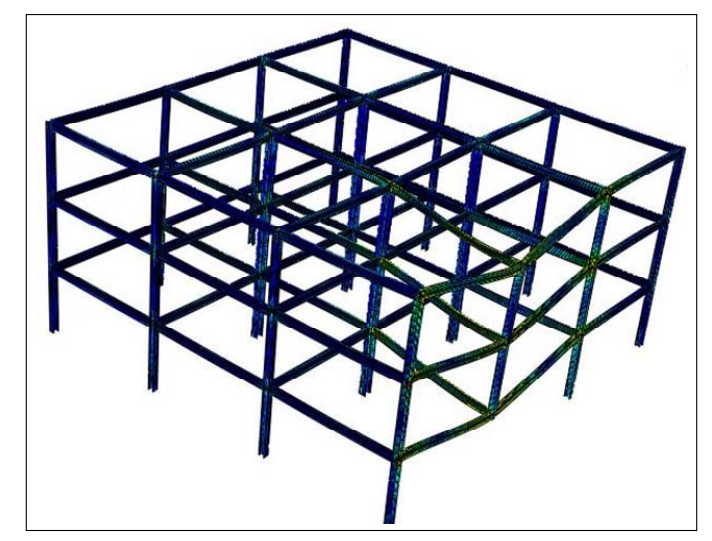

Figure 24. The maximum deformation for 3-D steel frame for 3-story building for interior column removed with equal span.

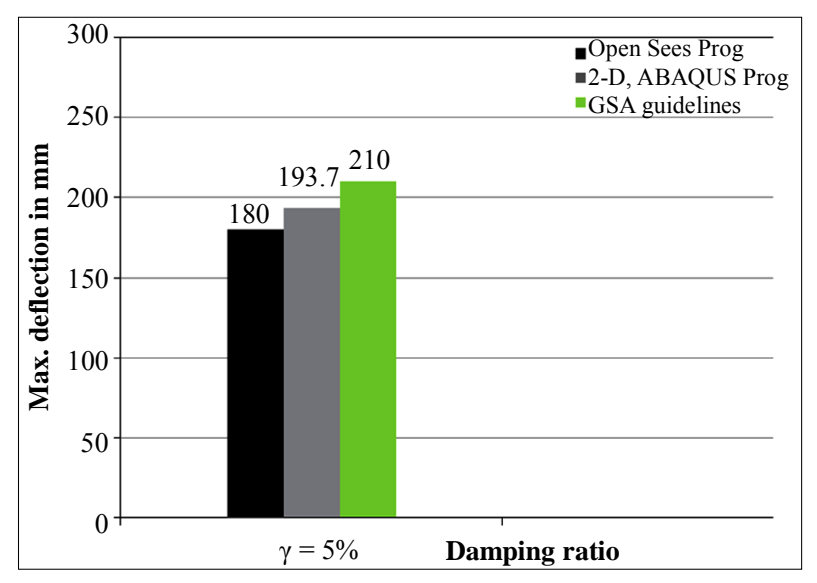

Figure 25. The maximum lateral deflections of Jinkoo (2008) [16], 2-D steel frame with span ratio 1:0.6 for interior column removed. faster return to its rest position without ever overshooting.

Figure 29 presented the maximum lateral deflection gets from the analysis and the experimental case [18]. The maximum lateral deflection was higher than the one get from experimental test by $27 \%$, the difference between the analysis and the experimental due the rate of loading and the scale of the problem, i.e. that it involves a full system, has made testing difficult. From Figure 29, the maximum lateral deflection gets at the ultimate load capacity $50 \mathrm{KN}$ for the case of loading where the load was applied increasingly with time the maximum deflect-

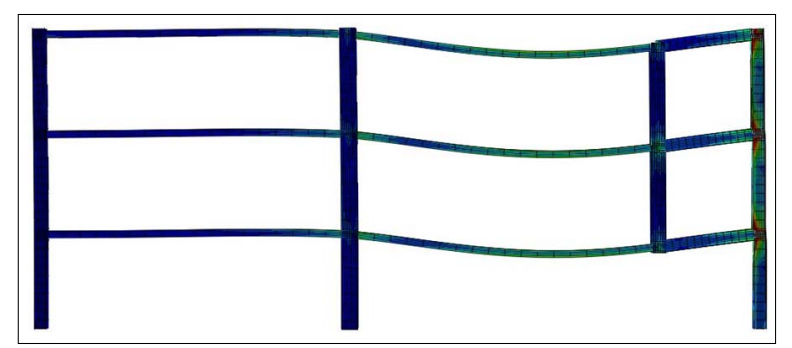

Figure 26. The maximum deformation for 2-D steel frame for 3-story building for interior column removed and span ratio 1:0.3.

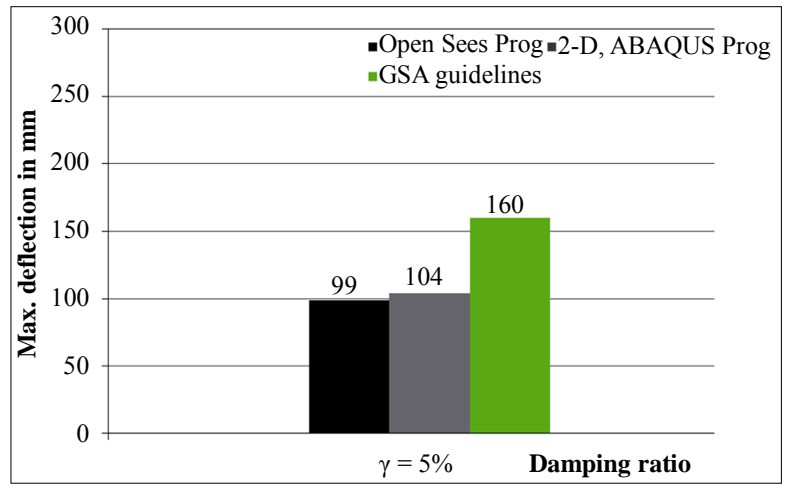

Figure 27. The maximum lateral deflections of Jinkoo (2008) [16], 2-D steel frame with span ratio 1:0.3 for interior column removed.

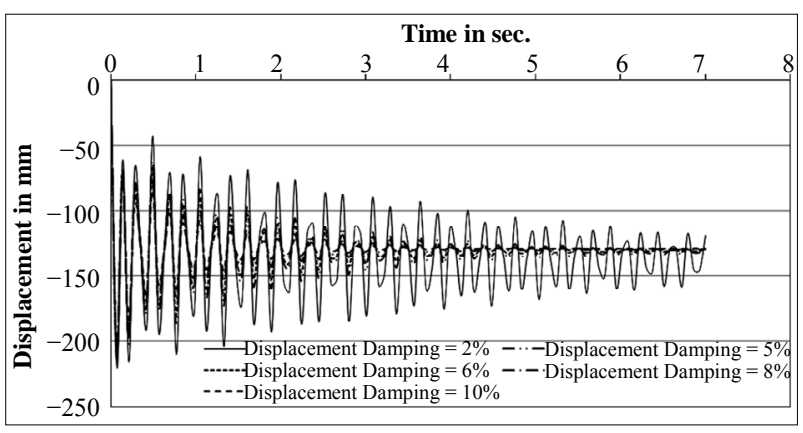

Figure 28. The time history of the vertical displacement for the internal column removed for 3-story building with equal span. 


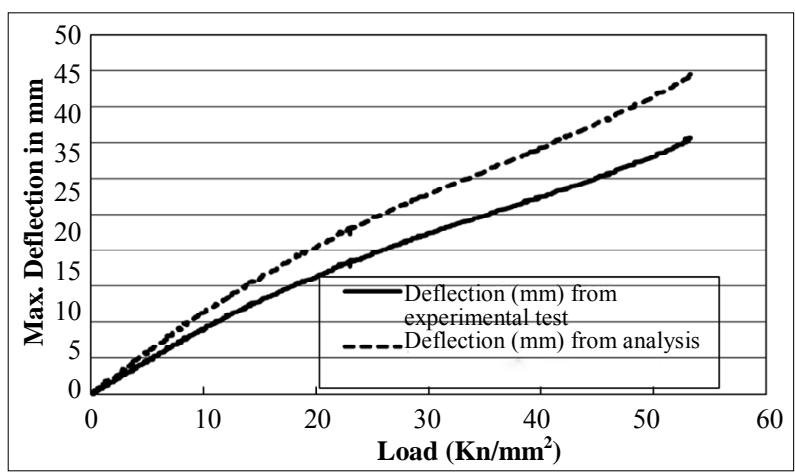

Figure 29. The maximum lateral deflection for internal column removed from the analysis and experimental test.

tion would be measured and get around $35-36 \mathrm{~mm}$.

\section{Conclusions}

Nonlinear finite element models investigating the progressive collapse of steel frames have been developed and reported in this paper. The finite element models have accounted for the nonlinear material of the steel frames and the nonlinear geometry was also considered. The investigated steel frames had different geometries and different damping ratios. Overall, the paper addresses how multistory frames would behave when subjected to local damage or loss of a main structural carrying element. The history behavior of the steel frames deformations and failure modes were investigated and discussed in this paper. The nonlinear finite element models accented the nonlinear material and geometry behavior of the steel frames. The study has shown that:

- By increasing damping ratios in dynamic analysis the maximum lateral deflection decreased for all frames.

- The progressive collapse potential decreased as the number of story increased since more structural members participate in resisting progressive collapse.

- The nonlinear dynamic analysis method provided a realistic representation of the progressive collapse behavior.

- The increase only in the girder size for the purpose of preventing progressive collapse may result in weak story when the building is subject to seismic load. The formation of weak story can be prevented by increasing the column size in such a way that the strong column-weak beam requirement is satisfied.

The maximum lateral deflection obtained for internal column-removed case using the 3D-model was slightly higher (within 2\%) than that obtained for internal columnremoved case using the $2 \mathrm{D}$-model.

\section{REFERENCES}

[1] R. E. Mc Connel and S. J. Kelly, "Structural Aspects of
Progressive Collapse of Warehouse Racking," The Structural Engineer, Vol. 61A, No. 11, 1983, pp. 343-347.

[2] F. Casciati and L. Faravelli, "Progressive Failure for Seismic Reliability Analysis," Engineering Structures, Vol. 6, No. 2, 1984, pp. 97-103. http://dx.doi.org/10.1016/0141-0296(84)90002-6

[3] A. J. Pretlove, "Dynamic Effects in Fail-Safe Structural Design," Proceedings, International Conference on Steel Structures: Recent Advances and their Application to Design, Budva, 1986, pp. 749-757.

[4] J. L. Gross and W. Mcguire, "Progressive Collapse Resistant Design," Journal of Structural Engineering, Vol. 109, No. 1, 1983, pp. 1-15.

[5] R. M. Bennett, "Formulation for Probability of Progressive Collapse," Structural Safety, Vol. 5, No. 1, 1988, pp. 67-77. http://dx.doi.org/10.1016/0167-4730(88)90006-9

[6] A. J. Pretlove, M. Ramsden and A. G. Atkins, "Dynamic Effects in Progressive Failure of Structures," International Journal of Impact Engineering, Vol. 11, No. 4, 1991, pp. 539-546.

[7] E. M. Smith, "Alternate Path Analysis of Space Trusses for Progressive Collapse," Journal of Structural Engineering, Vol. 114, No. 9, 1988, pp. 1978-1999.

http://dx.doi.org/10.1061/(ASCE)0733-9445(1988)114:9( $\underline{1978)}$

[8] R. B. Malla and B. B. Nalluri, "Dynamic Effects of Member Failure on Response of Truss Type Space Structure," Journal of Spacecrafts and Rockets, Vol. 32, No. 3, 1995, pp. 545-551. http://dx.doi.org/10.2514/3.26649

[9] K. Abedi and G. A. R. Parke, "Progressive Collapse of Single-Layer Braced Domes" International Journal of Space Structures, Vol. 11, No. 3, 1996, pp. 291-306.

[10] J. R. Gilmour and K. S. Virdi, "Numerical Modeling of the Progressive Collapse of Framed Structures as a Result of Impact or Explosion," 2nd International PhD Symposium in Civil Engineering, 1998.

[11] G. Kaewkulchai and E. B. Williamson, "Dynamic Behavior of Planar Frames during Progressive Collapse". 16th ASCE Engineering Mechanics Conference, University of Washington, Seattle, 2003.

[12] G. Kaewkulchai and E. B. Williamson, "Beam Element Formulation and Solution Procedures for Dynamic Progressive Collapse Analysis," Computers and Structures, Vol. 82, No. 7-8, 2004, pp. 639-651. http://dx.doi.org/10.1016/j.compstruc.2003.12.001

[13] K. Khandelwal and S. El-Tawil, "Collapse Behavior of Steel Special Moment Resisting Frame Connections," Journal of Performance of Constructed Facilities, Vol. 113, No. 5, 2007, pp. 646-665.

[14] J. Kim and J. Park, "Design of Steel Frames Considering Progressive Collapse," Steel and Composite Structures, Vol. 8, No. 1, 2008, pp. 85-98.

http://dx.doi.org/10.12989/scs.2008.8.1.085

[15] GSA, "Progressive Collapse Analysis and Design Guidelines for New Federal Office Buildings and Major Modernization Projects," The US General Services Administration, 2003. 
[16] J. Kim and J. Park, "Design of Steel Moment Frames Considering Progressive Collapse," Steel and Composite Structures, Vol. 8, No. 1, 2008, pp. 85-98. http://dx.doi.org/10.12989/scs.2008.8.1.085

[17] The Unified Facilities Criteria (UFC) 4-023-03, "Design of Buildings to Resist Progressive Collapse, Approved for
Public Release,” Department of Defense, 2005.

[18] K. S. Kandil, E. A. Ellobody and H. Eldehemy, "Experimental Investigation of Progressive Collapse of a Steel Frame," 2013. 